\title{
PEMERTAHANAN BAHASA SUNDA DI SENTRA KRAMIK PLERED
}

\author{
(Studi Kasus) \\ Tatang \\ Dosen FPBS UPI \\ e-mail: tatangtaufiq02@ymail.com
}

\begin{abstract}
Abstrak
Penelitian ini didasari oleh fenomena kontak bahasa yang terjadi di Sentra Kramik Plered Jawa Barat. Plered adalah salah satu daerah Sunda di Jawa Barat yang mayoritas masyarakatnya menggunakan bahasa Sunda sebagai bahasa pengantar sehari-hari. Bagaimanapun, fenomena kontak bahasa antara masyarakat Plered dengan para pelancong (peminat kramik) baik dari dalam negeri maupun luar negeri, akan menimbulkan fenomena multilingualisme; campur kode atau alih kode. Bagaimana masyarakat Plered mempertahankan bahasa daerah Sunda sebagai bahasa daerahnya, fenomena ini menjadi menarik untuk dikaji. Untuk mengetahui hal tersebut, peneliti melakukan wawancara dengan para pengrajin keramik dan observasi langsung terhadap transaksi jual beli di Sentra Kramik Plered. Dari hasil pengolahan data, disimpulkan bahwa upaya pemertahanan bahasa Sunda dilakukan melalui penamaan produk keramik (95\% berbahsa Sunda, $5 \%$ bahasa Asing), dalam percakapan sehari-hari antar orang dewasa dan antar anak-anak, dalam kegiatan formal kepala desa, dalam acara keagamaan, dalam transaksi jual beli yang penjualnya adalah orang dewasa. Bahasa Sunda kurang digunakan dalam peristilahan bahan baku, proses, dan alat pembuatan keramik, dalam penamaan toko, dalam pergaulan antar remaja, dan dalam transaksi jual beli yang penjualnya anak remaja.
\end{abstract}

Kata kunci: kontak bahasa, campur kode, alih kode, pemertahanan, bahasa daerah.

\section{SUNDANESE LANGUAGE MAINTENANCE AT THE CERAMIC CENTER IN PLERED}

\begin{abstract}
The present research is motivated by the language contact phenomena at the ceramic center, Plered, West Java. Plered is one of Sundanese speaking areas in West Java in which Sundanese is used as a daily language by the majority of the people. The language contact phenomena between people of Plered and domestic and international visitors (ceramic enthusiasts) give rise to multilingualism phenomena; code mixing or code switching. How people of Plered maintain Sundanese as their local language is the focal interest of this research. To meet that end, interviews with ceramic makers and direct observation of transaction at the ceramic center were deployed. Results indicate that Sundanese language maintenance is undertaken through the naming of ceramic products $195 \%$ in Sundanese and $5 \%$ in foreign language), in daily communications between adults and children, on formal occasions of the chief of the village, religious activities, and business transaction whose vendors are adults. Sundanese is less used in the naming of raw materials, process and ceramic-making tools, ceramic stores, interactions among teenagers and business transaction whose vendors are teenagers.
\end{abstract}

Key words: language contact, code mixing, maintenance, local language

\section{PENDAHULUAN}

Plered adalah salah satu kecamatan di Kabupaten Purwakarta Provinsi Jawa Barat yang sudah lama terkenal sebagai sentra industri keramik. Sebagai sentra keramik,
Plered menjadi kawasan wisata perdagangan yang banyak dikunjungi orang dari dalam dan luar negeri. Keramik yang dihasilkan selain untuk pangsa pasar dalam negeri juga sebagai komoditi ekspor ke mancanegara. 
Ditinjau dari sisi ekonomi, kedatangan para pembeli keramik, baik yang berasal dari dalam negeri maupun dari luar negeri, telah memberikan dampak positif terhadap pertumbuhan ekonomi masyarakatnya. Bahkan, berdasarkan daftar penyumbang Pendapatan Anggaran Daerah Kabupaten Purwakarta, Kecamatan Plered adalah penyumbang PAD terbesar untuk Kabupaten Purwakatra. Kondisi ini membuat Kecamatan Plered sebagai kecamatan yang mendapat perhatian khusus di Kabupaten Purwakarta (wikipedia.org/wiki/Plered, diunduh tanggal 12 Juni 2009).

Dilihat dari sisi sosiokultural dan sosiolinguistik, kedatangan banyak orang dari berbagai etnis itu dapat mempengaruhi budaya dan bahasa setempat. Interaksi perdagangan antara pengrajin dan pemesan, antara penjual dan pembeli, mau tidak mau akan menimbulkan kontak budaya dan kontak bahasa. Perilaku beradaptasi para pengrajin atau pedagang agar dapat berkomunikasi dengan pembeli telah menimbulkan fenomena berbahasa seperti alih bahasa, campur kode atau alih kode. Dalam kondisi demikian, akan muncul dalam masyarakat tersebut fenomena multilingualisme.

Walaupun tidak dapat dihindari, fenomena multilingualisme, dilihat dari sisi pemertahanan bahasa, adalah suatu masalah yang harus diantisipasi. Fenomena pemilihan bahasa, alih kode, dan campur kode yang tak terkendali, lama kelamaan akan mengakibatkan bahasa daerahnya mandul, tidak berkembang, bergeser dan akhirnya mengalami kematian. Untuk itu perlu dilakukan upaya pemertahanan dan pengembangan bahasa.

Fenomena multilingualisme, dilihat dari sisi pemertahanan bahasa, adalah suatu masalah yang harus diantisipasi. Fenomena pemilihan varian bahasa, alih kode, dan campur kode yang tak terkendali, lama kelamaan akan mengakibatkan bahasa daerahnya mandul, tidak berkembang, bergeser dan akhirnya mengalami kematian.
Untuk itu perlu dilakukan upaya pemertahanan bahasa.

Masalah pemertahanan bahasa yang akan kita bahas ini erat hubungannya dengan perencanaan bahasa (language planning), pembinaan bahasa (language maintenance), dan pengembangan bahasa (language development). Oleh sebab itu, pembahasan mengenai pemertahanan bahasa selalu terkait erat dengan perencanaan, pembianaan, dan pengembangan bahasa. Perencanaan, pembinaan dan pengembangan bahasa adalah upaya kongkrit untuk mempertahankan bahasa.

Menurut Rubin \& Jernudd (1973) hampir semua orang bisa melakukan perencanaan dan pembinaan bahasa. Pemerintah, tentu saja, memiliki kemampuan yang paling besar untuk melakukan dan mengeluarkan keputusan yang mempengaruhi bahasa, tetapi belum tentu yang paling berhasil. Sebab setiap upaya perencanaan dan pembinaan bahasa yang diselenggarakan oleh otoritas resmi, seperti negara atau gereja, masyarakat pembelajar atau penulis, hanya akan berhasil jika berkorelasi maksimal dengan usaha informal yang tak berlembaga sebagai bagian dari otoritas lokal yang lebih mudah diakses.

Keputusan Gereja Katolik Roma dua puluh tahun lalu yang mengijinkan masyarakat Latin menggunakan bahasa daerahnya adalah contoh dari perencanaan bahasa dalam domain agama. Beberapa negara memiliki lembaga bahasa untuk membuat keputusan penting mengenai penggunaan bahasa negaranya. Di negaranegara berbahasa Inggris, dua warga negara yang menyusun kamus memiliki pengaruh besar pada standarisasi ejaan dan makna kata yaitu Samuel Johnson di Inggris dan Noah Webster di Amerika Serikat (Rubin \& Jernudd,1973).

Pada awal ditemukannya percetakan, individulah yang memutuskan bagaimana bahasa yang digunakan dalam publikasi pertama, menetapkan preseden yang 
berpengaruh hingga ke taraf tertinggi dalam bahasa tulisan hingga beberapa waktu sesudahnya. Terjemahan Alkitab yang ke dalam bahasa Jerman yang dibuat Luther, salah satu karya paling awal yang dipublikasikan secara luas, memiliki pengaruh kuat pada standarisasi bahasa Jerman. Pada pertengahan abad kelima belas, William Caxton membawa salah satu alat percetakan ke Inggris dari Eropa daratan dan menggunakannya untuk mempublikasikan berbagai manuskrip. Dalam proses ini, ia bertindak sebagai editor untuk semua yang diterbitkannya dan ia mencoba untuk membuat keputusan yang konsisten tentang berbagai bentuk tatabahasa dan ejaan dalam manuskrip yang dia diterima (Fasold, 1984). Dengan cara ini, dia memiliki pengaruh kuat terhadap standardisasi bahasa Inggris dibandingkan orang lain yang hidup pada zaman yang berbeda (Fasold, 1984). Dalam abad kita dan hingga hari ini, misionaris yang melaksanakan program keaksaraan, yang sebelumnya tak tertulis, seringkali menjadi orang-orang yang memutuskan bagaimana bahasa dan dialek akan ditulis demi tujuan-tujuan penulisan.

Menurut Jernudd (1973) ada beberapa lembaga perencanaan dan pembinaan bahasa, selain pemerintah:

1) Lembaga nasional nonpemerintah, misalnya Singapore Chamber of Commerce yang menyusun dan mengeluarkan ujian bahasa dan manual untuk korespondensi bisnis dalam bahasa Melayu.

2) Lembaga nonnasional dan nonpemerintah, misalnya Shell Company menyediakan sendiri terminologi minyak dalam bahasa Melayu di Malaysia yang mempengaruhi perkembangan bahasa dalam pelatihan personil dan kebijakan.

3) Surat kabar fungsi koreksi cetakan.

4) Penulis, penyiar, wartawan.

Alat utama yang digunakan pemerintah dalam menerapkan keputusan perencanaan dan pembinaan bahasa adalah sistem pendidikan. Rubin (1971) menemukan beberapa kasus, seperti anakanak yang berbicara dalam bahasa Guaran Paraguai dan Gaelic Skotlandia di sekolah. Anak-anak dihukum secara fisik dan dilarang berbicara dalam bahasa tersebut di sekolahnya. Seorang guru memberitahu seorang anak untuk tidak mengatakan 'ain't'. Ini adalah contoh kecil dari penggunaan sistem sekolah untuk melaksanakan perencanaan bahasa, atau paling tidak pemertahanan bahasa.

\section{METODE}

Kondisi ekonomis masyarakat Plered dan kondisi geografis wilayahnya yang cukup rentang dari berbagai ancaman kebahasaan itulah yang menarik penulis untuk meneliti masyarakat Plered. Pertanyaan mendasar yang berusaha akan dijawab dalam tulisan ini adalah perencanaan bahasa yang bagaimanakah yang dilakukan oleh masyarakat Plered. Untuk memperoleh data yang dibutuhkan, peneliti menggunakan teknik observasi (participant observation) dan wawancara. Metode ini sangat mengutamakan aspek kealamiahan kemunculan perilaku berbahasa sehari-hari responden. Untuk itu, peneliti harus tinggal bersama komunitas yang diteliti (pengrajin dan pedagang keramik) dan menetap beberapa lama di tempat penelitian.

\section{HASIL DAN PEMBAHASAN \\ Pemertahanan Bahasa Sunda oleh Masyarakat Plered}

Pertahanan bahasa Sunda yang akan digambarkan merupakan hasil observasi langsung ke lokasi Desan Anjun dan Desa Bendul Kecamatan Plered Purwakarta Jawa Barat.

Untuk melihat model pemertahanan bahasa Sunda di Plered, saya akan membahasnya dalam empat bahasan; (1) bahasa yang digunakan (bahasa Sunda, bahasa Indonesia atau bahasa asing) untuk penamaan atau pelabelan toko-toko keramik 
yang berada di sepanjang jalan Anjun dan Bendul; (2) bahasa yang digunakan untuk penamaan atau pelabelan produk-produk keramik dari Desa Anjun; (3) bahasa yang digunakan untuk percakapan sehari-hari; oleh orang dewasa, oleh remaja dan oleh anak-anak; dan (4) bahasa yang digukanan dalam komunikasi formal atau kedinasan, dalam kegiatan keagamaan atau pengajian, dan dalam kegiatan jual beli.

Untuk mendapatkan data pertama, peneliti melakukan observasi langsung ke sekitar 40 toko di sepanjang jalan Anjun dan Bendul. Data yang terkumpul berupa nama toko yang dicatat, dan difoto oleh peneliti. Dan untuk memperoleh nama-nama produk keramik, peneliti melakukan survey ke enam toko keramik dan dua pengrajin/pabrik keramik. Namun dikarenakan tidak ada daftar produk yang tertulis, maka peneliti melakukan wawancara. Hasil wawancara dicatat dan direkam. Untuk mengetahui bahasa apa yang digunakan dalam percakapan sehari-hari oleh orang dewasa, peneliti mencoba melakukan observasi terhadap beberapa kelompok orang dewasa yang berusia sekitar 40-55 tahunan yang sedang berkomunikasi, di antaranya; satu peristiwa di rumah tangga, dua peristiwa di pabrik keramik, dan enam peristiwa di toko keramik. Data hasil observasi tersebut direkam untuk dianalisis. Sedangkan data komunikasi antar remaja hanya diperoleh dari dua peristiwa. Yang pertama di toko keramik yang kedua di dalam angkot. Data itu direkam dalam mp3. Demikian juga data komunikasi sehari-hasi di lingkungan anakanak. Peneliti hanya memperoleh data dari dua peristiwa saja, yaitu pada dua kelompok anak usia 8-10 tahunan yang sedang bermain bersama teman-temannya. Untuk mengetahui bahasa apa yang digunakan dalam kegiatan formal atau kedinasan, peneliti mencoba mengobservasi satu peristiwa komunikasi antara Kepala Desa
Anjun dengan para tamu yang datang ke desa tersebut. Data itu kemudian direkam. Untuk mengetahui bahasa apa yang digunakan dalam kegiatan keagamaan, peneliti hanya mengambil satu data saja yaitu dari peristiwa jumatan. Ceramah atau khutbah tersebut direkam. Sedangkan untuk mengetahui bahasa apa yang digunakan dalam kegiatan jual beli, peneliti mengobservasi komunikasi antara penjual dan pembeli di enam toko keramik. Data pembicaraan antara penjual dan pembeli itu direkam.

Data yang diperoleh umumnya atau sebagian besar (95\%) berupa komunikasi lisan. Selebihnya berupa foto atau gambar.

\section{Pengunaan Istilah atau Penamaan untuk Nama Toko dan Produk Keramik}

Berdasarkan hasil observasi terhadap toko-toko penjual keramik, 90\% (atau 36 toko dari 40 ) toko-toko keramik yang diobservasi, tidak memiliki nama atau label toko. Melihat kondisi ini, nampaknya masyarakat Plered belum terbiasa dengan penamaan tokonya. Hanya ada empat toko yang ada namanya. Dilihat dari sisi penggunaan bahasa, khususnya pada nama toko, tentu saja kondisi ini tidak dapat memberikan data yang dibutuhkan. Namun apabila peneliti perhatikan, ada satu diantara empat toko yang memberi nama tokonya dengan nama asing (bahasa Inggris: Krafel Craft ). Ia tidak menggunakan nama bahasa daerah atau bahasa Indonesia. Ini mengindikasikan bahwa pemilik toko tersebut lebih menyukai nama asing (bahasa Inggris) untuk menamai tokonya dibandingkan bahasa daerah atau bahasa Sunda. Namun sayang, ketika hari Jumat tersebut tokonya akan segera tutup, sehingga peneliti tidak sempat mewawancarai pemiliknya dan menanyakan alasan penamaan toko tersebut dengan bahasa asing. 


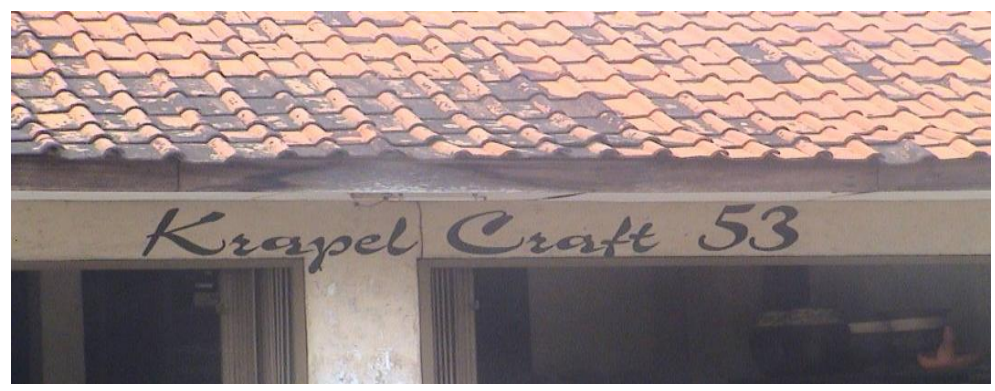

Gambar 1: Nama Toko Keramik di Plered

Pada beberapa toko keramik terdapat pula beberapa slogan atau papan informasi, tapi bukan nama toko. Bahasa yang digunakan untuk slogan atau papan informasi tersebut

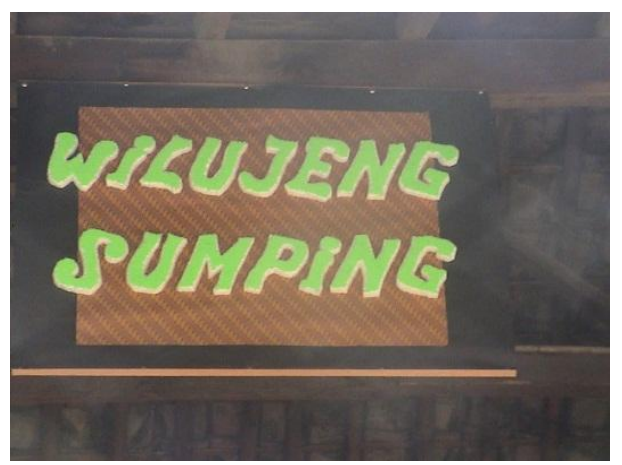

sangat beragam, ada yang menggunakan bahasa Indonesia, dan ada pula yang menggunakan bahasa Sunda, seperti pada gambar berikut ini.

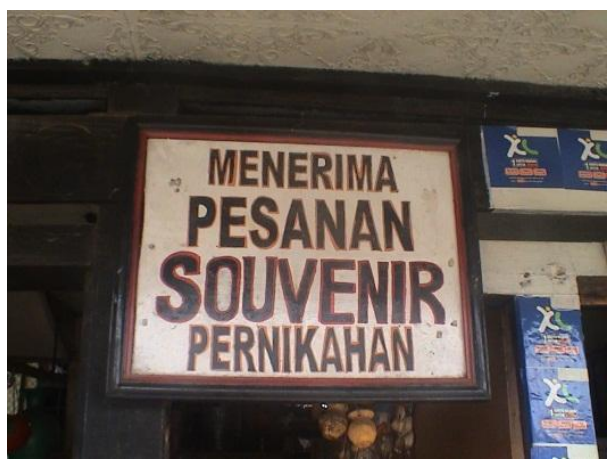

\section{Gambar 2: Bahasa Slogan di Toko Keramik}

Setiap produk yang dijual tentu saja memiliki nama masing-masing. Namun nama produk tersebut tidak dapat kami ketahui kecuali dengan cara menanyakan apa nama masing-masing produk tersebut. Tidak ada daftar khusus yang tertulis tentang nama-nama produk tersebut. Untuk mengetahui nama-nama produk, maka peneliti melakukan wawancara. Wawancara dilakukan kepada pengrajin senior $H$. Abubakar dan beberapa pengrajin lainnya.

Dari data yang diperoleh, hampir seluruh produk yang dihasilkan dari Plered tersebut diberi nama dalam bahasa Sunda seperti gentong, coet, mutu, pariuk, kendi dan sebagainya. Ada sebagian kecil nama produk yang kadang-kadang menggunakan bahasa Sunda, dan kadang menggunakan bahasa Indonesia seperti nama produk pas bunga, hampir sering penggunaannya dengan sebutan pot kembang. Bagaimana kalau ada pemesan dari luar negeri, sementara mereka belum begitu faham dengan nama-nama sunda tersebut? Untuk mengatasi hal itu cara yang dilakukan pengrajin adalah tetap memberi nama dalam bahasa Sunda, tapi disamping itu juga memberikan kode produk, seperti nama produk kendi, kode produk K03. Biasanya orang asing yang belum terbiasa dengan nama produk aslinya akan menggunakan kode produk. Ditinjau dari fenomena bahasa, penomena inipun adalah bagian dari fenomena alih kode.

Ada pula sebagian kecil nama produk yang berasal dari bahasa asing, walaupun produk itu juga diproduksi oleh pengrajin keramik Plered, seperti nama produk yang berlapis melamin disebut dengan nama guci atau porslen. Nama guci atau porslen tetap mereka gunakan, tanpa membuat nama pengganti atau perubahan nama. 
Pengunaan Istilah atau Penamaan dalam Bahan Baku, Proses Pembuatan, dan Alat-Alat Pembuatan Keramik

Berbeda dengan nama-nama produk yang hampir $95 \%$ berbahasa Sunda. Pada umumnya alat-alat yang digunakan untuk mengolah keramik tersebut menggunakan istilah atau nama asing. Hanya sebagian yang menggukanan bahasa Indonesia, dan sebagian kecil lagi menggunakan bahasa Sunda. Jadi, nama alat-alat yang digunakan untuk mengolah keramik tersebut sedikit sekali yang menggunakan istilah atau nama bahasa Sunda. Contoh beberapa nama alat untuk membuat keramik di kalangan pengrajin keramik di Kecamatan Plered.

Tabel 1: Beberapa Nama Alat Untuk Membuat Keramik

\begin{tabular}{llll}
\hline Bahasa Sunda & Bahasa Indonesia & Bahasa Asing & Bahasa Campuran \\
\hline puteran batu & - & kick wheel & - \\
\hline- & tungku bak & - & - \\
\hline- & - & gift & - \\
\hline- & - & oven slag & - \\
\hline- & - & - & oven botol $^{*}$ \\
\hline- & - & - & oven gas $^{*}$ \\
\hline- & - & - & mesin bolmil \\
\hline- & - & mixer & - \\
\hline- & - & filter press & - \\
\hline
\end{tabular}

Istilah-istilah dalam proses pembuatan keramik yang dipakai di kalangan pengrajin di Kecamapatan Plered sangat beragam, ada yang berbahasa Sunda, berbahasa Indonesia, dan ada pula yang berbahasa Asing. Namun apabila diperhatikan, ada kecenderungan tertentu dalam penamaan proses tersebut. Penamaan terhadap proses yang klasik, tidak modern dan tidak menggunakan mesin modern, cenderung berbasa Sunda. Sedangkan penamaan terhadap proses yang modern dan menggunakan mesin yang lebih canggih, cenderung berbasa Asing.
Kecenderungan lain adalah disesuaikan dengan dari mana mesin atau alat produksi keramik itu dibuat. Jika alat produksinya dibuat dari lokal (dari Indonesia/Plered) maka nama prosesnya berbahasa Sunda, contoh diputer, karna alat pemutarnya buatan lokal. Dan jika alat produksinya dibuat dari luar negeri, maka penamaannya berbahasa asing seperti stoneware, undergliss, dan sebagainya. Berikut ini beberapa istilah dalam proses pembuatan keramik.

Tabel 2: Beberapa istilah dalam proses pembuatan keramik

\begin{tabular}{lll}
\hline Bahasa Sunda & Bahasa Indonesia & Bahasa Asing \\
\hline diluluh & - & manual \\
\hline dileyekan & - & - \\
\hline- & diendapkeun* & - \\
\hline dipoe & - & - \\
\hline- & pembentukan & - \\
\hline diputer & - & - \\
\hline- & dicor & casting \\
\hline dicitak & dicetak & - \\
\hline- & di-slip & - \\
\hline- & pembakaran & - \\
\hline- & pembakaran rendah & - \\
\hline- & pembakaran tinggi & stoneware \\
\hline
\end{tabular}




\begin{tabular}{lll}
\hline- & - & finishing \\
\hline- & - & undergliss \\
\hline- & - & ofgliss \\
\hline digambar & digambar/ dilukis & - \\
\hline dihampelas & - & - \\
\hline \multicolumn{2}{|l}{ Keterangan: *campuran antara bahasa Indonesia dan Sunda } &
\end{tabular}

Demikian pula pada istilah atau nama bahan baku yang dipakai dikalangan pengrajin di Kecamapatan Plered. Ada kecenderungan, jika bahan bakunya berasal dari asing, maka nama bahan tersebut berbahasa asing seperti caolin, walaupun sebenarnya bahan baku tersebut sekarang sudah ada di Indonesia. Tidak lagi di impor.

Tabel 3: Beberapa istilah atau nama bahan baku keramik

\begin{tabular}{lll}
\hline Bahasa Sunda & Bahasa Indonesia & Bahasa Asing \\
\hline- & tanah liat & plastis/ clay \\
\hline- & - & caolin \\
\hline- & kuarsa & - \\
\hline- & - & pelspat \\
\hline
\end{tabular}

Namun ada satu hal yang menarik, ketika ditanya mengapa tanah liat, bahan baku asli dari Plered tapi istilah atau nama yang umumnya digunakan dikalangan pengrajin clay atau plastis (bahasa asing). Alasannya karena orang Belanda lah yang pertama kali mengembangkan kerajinan keramik ini, sehingga banyak istilah asing yang dipakai dalam pembuatan keramik ini, dan orang Sunda mengikutinya, tanpa diadakan penyetaraan bahasa atau perubahan istilah.

\section{Penggunaan Bahasa Dalam Komunikasi Sehari-Hari oleh Orang Dewasa, Remaja dan Anak-Anak}

Untuk mengetahui komunikasi seharihari oleh orang dewasa peneliti juga memanfaatkan peristiwa komunikasi dari sembilan peristiwa, di antaranya adalah satu peristiwa komunikasi di keluarga $\mathrm{H}$. Abubakar, dua peristiwa komunikasi di pabrik keramik, dan enam peristiwa komunikasi antara penjual dan pembeli keramik (orang dewasa). Semuanya oleh peneliti layak dijadikan data karena mereka adalah warga yang sudah lama menetap di wilayah Plered tersebut.

Percakapan $\mathrm{H}$ Abubakar dengan beberapa orang tamu, anggota keluarga, dan beberapa kerabatnya yang pada waktu itu menemui H. Abubakar, oleh peneliti diobservasi dan dicatat sebagai data. Ketika H. Abubakar menyambut para tamu ia menggunakan bahasa daerah sepenuhnya. Demikian pula ketika ia bercakap-cakap dengan para tamu, angota keluarga dewasa lainnya, dan ketika bercakap-cakap dengan pegawainya.

Ada satu peristiwa komunikasi yang juga cukup menguatkan. Ketika seorang pembeli (yang berasal dari Sunda) berusaha menawar barang keramik dengan menggunakan bahasa Indonesia kepada penjual (seorang dewasa), penjual tersebut tetap menjawab atau berkomunikasi dengan bahasa Sunda. Pembeli menggunakan bahasa Indonesia tapi penjual tetap menggunakan bahasa Sunda. Walaupun demikian, fenomena ini masih perlu dipertanyakan lebih lanjut.

Namun ada satu kejadian yang menarik yang tampak dari komunikasi H. Abubakar dengan seorang anak kecil, cucunya. Peristiwa itu juga didapati oleh peneliti ketika hendak melakukan observasi di sebuah toko. Pemilik toko tersebut sedang menggendong anak kecil yang menurut peneliti adalah anaknya. Dari dua peristiwa itu ternyata, baik H. Abu Bakar, maupun 
pemilik toko, berbicara kepada anak kecil dengan menggunakan bahasa Indonesia, bukan bahasa Sunda. Fenomena ini memberikan kesan bahwa ada upaya untuk menggantikan peran bahasa daerah yaitu bahasa Sunda sebagai bahasa pengantar sehari-hari oleh bahasa Indonesia kepada anak kecil di lingkungan keluarganya. Namun itu tampaknya belum mengjegala secara luas. Sebab pada keluarga lain yang peneliti temukan, mereka masih menggunakan bahasa daerah dalam percakapan sehari-hari antara orang tua kepada anak-anaknya.

Data komunikasi antar remaja di Kecamatan Plered, peneliti dapatkan dari dua peristiwa. Yaitu ketika seorang remaja sebagai penjual yang sedang melayani tiga orang pembeli keramik, dan peristiwa komunikasi tiga remaja seusia SMP yang sedang berbincang-bincang dengan temannya di dalam angkot. Dari peristiwa pertama peneliti mencatat bahwa seorang anak remaja asal Purwakarta itu berusaha menyesuaikan bahasanya dengan bahasa yang digunakan oleh pembeli. Ketika ada seorang pembeli menggunakan bahasa Sunda, iapun menggunakan bahasa Sunda. Tapi ketika pembeli lain bertanya dengan menggunakan bahasa Indonesia, iapun menjawabnya dengan menggunakan bahasa Indonesia. Bahkan ketika pembeli lain berusaha menggunakan bahasa Sunda (walaupun agak kaku), tapi penjual yang remaja itu tetap menggunakan bahasa Indonesia. Sepertinya ada kecenderungan penjual itu lebih suka berbahasa Indonesia, ketimbang berbahasa Sunda.

Dari peristiwa kedua, yaitu percakapan antar remaja di dalam angkot, sekitar \pm 10 menit peneliti mengobservasinya, mereka semuanya menggunakan bahasa Indonesia secara penuh. Tidak ada bahasa Sunda yang diucapkan dalam percakapan itu.

Data penggunaan bahasa sehari-hari antar anak-anak peneliti peroleh dari dua kelompok anak usia sekitar 8 - 10 tahunan yang sedang bermain. Kelompok pertama terdiri dari tiga anak, sedangkan kelompok kedua terdiri dari enam anak. Percakapan mereka diobservasi dan direkam. Dari percakapan itu diperoleh data bahwa bahasa yang digunakan oleh anak-anak itu sepenuhnya bahasa Sunda. Tidak ada katakata bahasa Indonesia yang terucap dari perbincangan mereka. Selanjutnya ketika ditanya apakah disekolah guru-guru mereka menggunakan bahasa Sunda atau bahasa Indonesia dalam mengajar? Secara spontan anak-anak itu menjawab 'campur'. Maksudnya di sekolah guru-guru mereka saat mengajar, kadang menggunakan bahasa Sunda, dan terkadang pula menggunakan bahasa Indonesia. Namun belum diketahui secara pasti apakah anak-anak tersebut menggunakan bahasa Sunda itu karena belum mampu berbahasa Indonesia atau sebetulnya mereka sudah mampu tapi mereka lebih menyukai bahasa Sunda. Peneliti mengasumsikannya bahwa walaupun mereka sudah mampu atau tahu tentang bahasa Indonesia, tapi mereka lebih senang menggunakan bahasa Sunda untuk bahasa pergaulan sesama temannya. Setelah diamati lebih jauh, ternyata bahasa pengantar dalam keluarganya pun menggunakan bahasa Sunda. Data itu peneliti peroleh ketika beberapa orang tua berbicara kepada anaknya. Dalam pembicaraan itu, bahasa yang mereka pergunakan adalah bahasa Sunda.

\section{Penggunaan Bahasa dalam Komunikasi Kegiatan Formal, Kegiatan Keagamaan, dan Kegiatan Jual Beli}

Untuk memperoleh data tentang bahasa apa yang dipergunakan dalam kegiatan formal ini, peneliti mencaoba mengobservasi penggunaan bahasa yang digunakan oleh Kepala Desa Anjun, sebuah desa sentra produksi keramik. Pada saat itu ada tiga orang tamu (dan saya, bertindak sebagai observer) yang berkunjung secara formal ke Kepala Desa tersebut. Dengan membawa surat resmi para tamu itu mengutarakan maksud dan tujuannya berkunjung ke desa Anjun. Pada awal pembicaraannya, para tamu itu 
menggunakan bahasa Indonesia. Dan Kepala Desa itu menyambut tamu tersebut dengan menggunakan bahasa Sunda. Selanjutnya para tamu itupun berbicara dalam bahasa Sunda. Sedangkan Kepala Desa, dengan gaya bahasa sundanya yang sangat kental, ia tetap menggunakan bahasa Sunda. Setelah ditanya lebih jauh, menurut pengakuannya, memang dia terbiasa menggunakan bahasa Sunda dalam kegiatan apapun, baik formal ataupun tidak formal.

Bagaimana dengan dokumen tertulis. Apa bahasa yang digunakan untuk dokumen tertulis yang resmi. Peneliti memperoleh data dari beberapa dokumen yang ada, seperti daftar penyumbang PAD, pengumuman hasil pemilu, dan sebagainya, bahwa bahasa yang digunakan dalam dokumen-dokumen resmi di Desa Anjun tersebut menggunakan bahasa Indonesia.

Untuk memperoleh data bahasa apa yang digunakan dalam kegiatan keagamaan. Peneliti mencoba mengobservasi penggunaan bahasa yang digunakan oleh penceramah sebelum salat jumat, dan khotib ketika khutbah jumat. Seperti pada umumnya, dalam kegiatan keagamaan, bahasa Arab (ungkapan salawat, salam, ayat Alquran dan Hadits) sangat kental digunakan. Itu adalah fenomena yang sangat wajar untuk ranah-ranah keagamaan. Yang ingin peneliti kaji selanjutnya, selain bahasa Arab tersebut, bahasa apa yang digunakan sebagai bahasa pengantarnya? Dari peristiwa itu diketahui bahwa dalam kegiatan keagamaan bahasa yang digunakannya adalah bahasa Sunda. Bahkan peneliti hampir tidak mendengar satu katapun dari penceramah tersebut yang berbahasa Indonesia. Bahasa Sunda digunakan secara penuh dalam kegiatan keagamaan tersebut.

Selain pada kegiatan tersebut, peneliti juga mencoba menayakan kepada beberapa ibu pengajian. Walaupun data ini tidak alamiah, tapi mungkin dapat dijadikan sebagai penguat data pertama. Berdasarkan hasil wawancara peneliti terhadap dua orang ibu pengajian yang berusia 45-50 tahunan itu, diperoleh informasi bahwa pada kegiatan pengajian yang diikutinya selalu menggunakan bahasa Sunda, kecuali jika ada penceramah dari luar daerah Sunda, seperti dari Jakarta, atau Cirebon. Selama penceramah itu orang Sunda, bahasa yang digunakannya sebagai pengantarnya adalah bahasa bahasa Sunda.

Dan untuk mengetahui bahasa apa yang digunakan dalam transaksi jual beli? Peneliti mencoba mendatangi enam toko keramik di sekitar jalan Anjun dan tiga toko keramik di sekitar jalan Bendul. Dari seluruh percakapan yang diobservasi dan direkam oleh peneliti, secara umum atau kebiasaan para penjual keramik berkomunikasi dengan pembelinya dalam bahasa Sunda. Jika pembeli itu diketahui orang Sunda, walaupun pembeli tersebut menggunakan bahasa Indonesia, maka penjual keramik orang dewasa umumnya melayaninya dengan menggunakan bahasa Sunda. Apalagi jika pembelinya menggunakan bahasa Sunda, penjual pun akan menggunakan bahasa Sunda. Namun di beberapa toko juga kami dapati bahwa terkadang penjual menyesuaikan bahasa yang digunakannya dengan bahasa pembeli. Jika pembelinya berbahasa Sunda, penjual tersebut menggunakan bahasa Sunda. Apabila pembeli menggunakan bahasa Indonesia maka penjual mengunakan bahasa Indonesia campur Sunda. Bahkan di beberapa toko didapati, ketika pembeli menggunakan bahasa Indonesia, penjualnya tetap menggunakan bahasa Sunda, tidak menyesuaikan dengan bahasa pembeli. Peneliti tidak mendapati data, penjual atau pemilik toko orang dewasa menggunakan bahasa Indonesia secara penuh ketika pembelinya berbahasa Indonesia. Ketika pembelinya berbahasa Indonesia, penjual menggunakan bahasa Indonesia campur Sunda. Berbeda ketika pembelinya berbahasa Sunda, maka penjual tersebut melayaninya dengan menggunakan bahasa Sunda penuh. Itu kasus jika penjualnya adalah orang dewasa. 
Ada sedikit yang menarik bahwa fenomena itu agak berbeda jika penjualnya remaja. Peneliti sempat mengobservasi sebuah toko keramik yang penjualnya remaja usia 20 tahunan. Dari observasi yang dilakukan peneliti terhadap penjual yang remaja itu, bahwa ia akan menggunakan bahasa Sunda secara penuh jika pembelinya berbahasa Sunda. Ia menggunakan bahasa Indonesia secara penuh jika pembelinya berbahasa Indonesia. Bahkan terkesan penjual yang remaja itu lebih suka menggunakan bahasa Indonesia. Itu terbukti ketika ada penjual yang berbahasa
Indonesia mencoba berkomunikasi dengan menggunakan bahasa Sunda (walaupun agak kaku) tapi penjual yang remaja itu tetap menjawabnya dengan bahasa Indonesia, tidak dengan bahasa Sunda seperti yang dilakukan pembeli. Jadi ada perbedaan sikap berbahasa antara penjual yang remaja dengan penjual yang dewasa. Yaitu ketika pembeli berbahasa Indonesia, penjual yang remaja menggunakan bahasa Indonesia secara penuh, sedangkan penjual yang dewasa tetap mengunakan bahasa Sunda atau mengunakan bahasa Indonesia campur Sunda.

Tabel 4: Pemetaan pemilihan bahasa antara penjual dan pembeli

\begin{tabular}{cclc}
\hline No. & PEMBELI & \multicolumn{2}{c}{ PENJUAL } \\
\cline { 3 - 4 } & & \multicolumn{1}{c}{ Dewasa } & Remaja \\
\hline 1. & Berbahasa Sunda & Berbahasa Sunda & Berbahasa Sunda \\
\hline \multirow{2}{*}{2.} & Berbahsa Indonesia & $\begin{array}{l}\text { berbahasa Indonesia } \\
\text { campurahasa Indonesia }\end{array}$ & \\
\cline { 3 - 3 } & & berbahsa Sunda & \\
\hline
\end{tabular}

\section{SIMPULAN}

Plered adalah sentra keramik di Purwakarta Jawa Barat yang banyak berinteraksi dengan masyarakat luar, baik dari dalam negeri maupun dari luar negeri, baik yang datang sebagai pembeli produk kerajinan, mupun sebagai wisatawan.

Interaksi antara masyarakat Plered dan pendatang tersebut menimbulkan fenomena sosial, budaya, dan berbahasa. Di antara fenomena berbahasa yang terjadi adalah pemilihan bahasa, adaptasi bahasa, alih kode, dan campur kode. Jika tidak dibuat perencanaan bahasa yang matang, fenomena-fenomena tersebut akan berdampak pada pergeseran bahasa daerahnya yaitu bahasa Sunda, bahkan bisa mengakibatkan kematian bahasa itu. Oleh karena itu perlu ada upaya perncanaan bahasa.

Perncanaan yang baik adalah yang mempertimbangkan aspek biaya-manfaat, serta aspek keberterimaan. Maksudnya bagaimana agar perencanaan itu berfungsi efektif walaupun dengan biaya rendah.
Untuk itu perlu ada analisis kondisi bahasa daerah di masyarakat tersebut.

Dari hasil pembahasan di atas dapat disimpulkan bahwa:

1) Masyarakat Plered adalah masyarakat Sunda yang sampai saat ini menjunjung tinggi budaya dan bahasa Sunda. Namun demikian, ada beberapa gejala yang diprediksi akan melunturkan atau menggeser bahasa Sunda oleh bahasa Indonesia. Seperti tergambar pada komunikasi antar remaja, dan komunikasi antara orang tua kepada cucunya yang menggunakan bahasa Indonesia.

2) Masyarakat Plered belum terbiasa untuk memberi nama pada tokonya. Dari 40 toko yang disurvei hanya empat toko yang memiliki nama toko.

3) Penggunaan slogan atau informasi yang ada di toko-toko masih beragam, ada yang berbahasa Sunda dan ada yang berbahasa Indonesia.

4) Belum ada dokumen resmi tentang daftar nama produk dan daftar istilah 
untuk bahan baku, proses, dan alat produksi. Penamaan produk keramik 95\% berbahsa Sunda, dan hanya 5\% saja yang menggunakan bahasa Asing, seperti guci, porslen. Hal itu disebabkan karena bahan bakunya awalnya dihasilkan dari luar negeri (impor).

5) Penggunaan istilah untuk bahan baku, proses, dan alat pembuatan keramik sangat beragam. Bahkan sebagian besar istilah untuk bahan baku, proses, dan alat pembuatan keramik adalah dalam asing, dan hanya sebagian kecil saja yang menggunakan istilah bahasa Sunda atau Indonesia. Alasannya adalah karena yang pertama kali mengembangkan keramik ini adalah bangsa asing (Belanda), alat-alat produksi yang canggih juga didatangkan dari luar negeri, termasuk beberapa bahan bakunya (impor), walaupun saat ini semuanya ada di Indonesia.

6) Orang dewasa di Plered, dalam percakapan sehari-hari selalu menggunakan bahasa Sunda, demikian pula anak-anak usia SD. Berbeda dengan anak remaja usia SMP. Anakanak remaja di Plered lebih sering menggunakan bahasa Indonesia ketimbang bahasa daerahnya (Sunda). Hal ini diprediksi karena mereka lebih banyak berkomunikasi dengan sesamanya yang berbahasa indonesia, dibandingkan dengan orang tua atau keluarganya yang berbahasa Sunda. Juga dimungkinkan karena pengaruh kominasi di sekolahnya (SMP) yang lebih sering menggunakan bahasa Indonesia dibanding bahasa Sunda.

7) Dalam ranah kegiatan formal seperti yang dilakukan kepala desa, bahasa yang digunakan dalam komunikasi lisan adalah bahasa daerah (Sunda). Namun dalam komunikasi tulisan, dokumentasi tertulis atau surat pengumuman, menggunakan bahasa Indonesia.
8) Seperti halnya dalam pergaulan antar orang tua, atau dalam pergaulan antar anak, dalam ranah keagamaan yang dilakukan masysrakat Plered, sepenuhnya menggunakan bahasa Sunda.

9) Dalam ranah jual beli, penjual orang dewasa cenderung mempertahankan bahasa Sunda, walaupun pembelinya berbahasa Indonesia (tapi orang Sunda). Namun demikian, jika menurut penjual bahwa pembeli itu bukan orang Sunda, maka ia akan alih kode menggunakan bahasa Indonesia. Berbeda dengan penjualnya anak remaja. Ia akan dengan mudah melakukan alih kode sesuai dengan bahasa yang digunakan pembeli. Tidak ada upaya mempertahankan pemakaian bahasa daerah.

\section{PUSTAKA RUJUKAN}

Fasold, R. (1984). The Sociolinguistics of Society (Introduction to Sociolinguistics). Oxford Basil Blackwell Publisher Ltd.

Jernudd, B.H., 1973, Towards A Theory of Language Planning. Honolulu: The University Press of Hawaii.

Rubin, Joan \& Bjorn H. Jernudd.1973, Can Language Be Planned, Honolulu: The University Press of Hawaii.

wikipedia.org/wiki/Plered, Posting tanggal 12 Juni 2009.

\section{UCAPAN TERIMA KASIH}

Penulis mengucapkan kepada berbaga pihak yang telah membantu dalam penelitian dan penulisan artikel ini, baik kepada pemerintahan dan masyarakat Plered, teman sejawat maupun para mahasiswa linguistik UPI. Ucapan terimakasih terutama saya ucapkan untuk Kepala Desa Plered Purwakarta Jawa Barat beserta seluruh stafnya, para pemilik kerajinan, para pemilik toko keramik, para pedagang toko keramik, dan masyarakat Plered lainnya. 